\title{
ASPEK STILISTIKA DALAM ANTOLOGI CERPEN MASTERA DARI PEMBURU KE TERAPEUTIK PUSAT BAHASA DEPARTEMEN PENDIDIKAN NASIONAL DAN PEMBELAJARANNYA DI SMP
}

\author{
Soli $^{1}$, Sukirno ${ }^{2}$ \\ ${ }^{1,2}$ Program Studi Magister Pendidikan Bahasa dan Sastra Indonesia, \\ Univeristas Muhammadiyah Purwokerto
}

Email: solispd5@gmail.com, sukirnopwt56@gmail.com

\begin{abstract}
Abstrak
Tujuan penelitian ini adalah untuk (1) mendeskripsikan aspek bahasa figuratif dalam Antologi Cerpen Mastera Dari Pemburu ke Terapeutik Pusat Bahasa Departemen Pendidikan Nasional, (2) mendeskripsikan fungsi bahasa dalam Antologi Cerpen Mastera Dari Pemburu ke Terapeutik Pusat Bahasa Departemen Pendidikan Nasional, dan (3) mendeskripsikan pembelajaran stilistika Antologi Cerpen Mastera Dari Pemburu ke Terapeutik Pusat Bahasa Departemen Pendidikan Nasional pada siswa SMP. Penelitian ini menggunakan pendekatan stilistika. Sumber data dalam penelitian ini adalah teks-teks yang mengandung bahasa figuratif yang terdapat dalam Antologi Cerpen Mastera Dari Pemburu ke Terapeutik. Teknik pengumpulan data digunakan teknik dokumentasi. Instrumen utama penelitian ini yaitu human instrument atau peneliti sebagai instrumen utama dibantu kartu dan pencatan data. Teknik analisis data penelitian digunakan content analysis (analisis isi) dengan cara teknik reduksi data, sajian data, dan verifikasi atau simpulan. Berdasarkan pembahasan hasil penelitian diketahui bahwa (1) pemakaian bahasa figuratif dalam Antologi Cerpen Mastera Dari Pemburu ke Terapeutik terdapat delapan aspek yaitu idiom, simile, metafora, metonomia, personifikasi, hiperbola, asosiasi dan retoris. (2) fungsi bahasa yang terdapat dalam antologi tersebut meliputi fungsi personal, fungsi instrumental, fungsi interpersonal, fungsi referensial, dan fungsi imajinatif, dan (3) pembelajaran stilistika Antologi Cerpen Mastera Dari Pemburu ke Terapeutik disesuaikan dengan Kurikulum 2013 yang dirumuskan dalam RPP yaitu pada KI 3/3.6 dan KI 4/4.6 yang meliputi kompetensi pengetahuan dan kompetensi keterampilan tentang aspek kebahasaan cerita pendek.
\end{abstract}

Kata kunci: statistik cerpen, antologi cerpen mastera dari pemburu ke terapeutik, pembelajarannya di SMP

\begin{abstract}
The purpose of this study was to (1) describe aspects of figurative language in the Anthology of Mastera Short Stories From Hunter to Therapeutic Language Centers of the Ministry of National Education, (2) describe the language functions in the Anthology of Mastera Short Stories from Hunter to Therapeutic Language Centers of the Ministry of National Education, and (3) describe the learning of the stylistics of Mastera Short Story Anthology From Hunter to Therapeutic Language Centers of the Ministry of National Education in junior high school students. This research uses a stylistic approach. The source of data in this study are texts that contain figurative language contained in the Anthology of Mastera Short Stories From Hunter to Therapeutic. Data collection techniques using documentation techniques. The main instrument of this research is the human instrument or researcher as the main instrument assisted by cards and data recording. Research data analysis techniques using
\end{abstract}


content analysis (content analysis) by means of data reduction techniques, data presentation, and verification or conclusions. Based on the discussion of research results it is known that (1) aspects of figurative language contained in the Anthology of Mastera Short Stories From Hunter to Therapeutic namely idiom, simile, metaphor, metonomia, personification, hyperbole, association and rhetoric. (2) the language functions contained in the anthology include personal functions, instrumental functions, interpersonal functions, referential functions, and imaginative functions, and (3) learning the stylistics of Mastera Short Story Anthology from Hunter to Therapeutic adjusted to the 2013 Curriculum which is formulated in the RPP namely at KI 3 / 3.6 and KI 4 / 4.6 which included knowledge competencies and skills competencies about the linguistic aspects of the short story.

Keywords: short story stylistics, anthology of mastera short stories from hunters to therapeutic, learning in middle school

\section{PENDAHULUAN}

Suatu karya sastra merupakan sebuah karya yang pada hakikatnya dibuat dengan mengedepankan aspek keindahan di samping keefektifan penyampaian pesan. Keindahan dalam karya sastra dapat diwujudkan melalui media bahasa. Media bahasa merupakan sarana yang digunakan pengarang untuk menyampaikan buah pikiran dan imajinasinya dalam proses penciptaan karya sastra.

Sejalan dengan itu, Wicaksono (2014: 1), mengemukakan bahwa sastra merupakan seni kreatif yang objeknya adalah manusia dan kehidupan dengan menggunakan bahasa sebagai mediumnya. Media bahasa yang dipakai dalam suatu karya sastra merupakan kemampuan seorang penulis dalam memilih kata yang bertujuan untuk memenuhi kebutuhan apa yang disampaikan melalui tulisannya dengan gaya kekhasannya. Berdasarkan hal tersebut, dapat disimpulkan bahwa setiap penulis memiliki cara dalam mengemukakan gagasan dan gambarannya menggunakan efek-efek tertentu bagi pembacanya.

Efek-efek tersebut dapat kita lihat melalui salah satu bentuk karya sastra, yaitu cerpen. Bahasa yang disusun oleh seorang pengarang dalam sebuah karya sastra (dalam hal ini cerpen) sering memberikan efek-efek tertentu, entah melalui pilihan katanya, citraannya, gaya bahasa, maupun gaya kalimat yang digunakan sehingga mempengaruhi jiwa seorang pembaca.

Secara menyeluruh kajian stilistika berperan untuk membantu menganalisis dan memberikan gambaran secara lengkap mengenai media bahasa sebagai sebuah karya sastra. Sejalan dengan itu, Abraham mengemukakan bahwa stilistika adalah cara pemakaian gaya bahasa dalam karangan atau bagaimana seorang pengarang mengungkapkan sesuatu yang akan diungkapkan (Imron, 2008: 1).

Secara umum, ruang lingkup telaah stilistika mencakupi diksi atau pilihan kata (pilihan leksikal), struktur kalimat, majas, pencitraan, pola rima, dan mantra yang digunakan seorang sastrawan atau yang terdapat dalam karya sastra, atau dengan kata lain, aspek-aspek bahasa yang ditelaah dalam studi stilistika meliputi intonasi, bunyi, kata, dan kalimat, sehingga lahirlah gaya intonasi, gaya bunyi, gaya kata, dan gaya kalimat (Sujiman: 13-14).

Cerita pendek (cerpen sebagai genre fiksi) merupakan rangkaian peristiwa yang terjalin menjadi satu yang di dalamnya terjadi konflik antartokoh atau dalam diri tokoh itu sendiri yang digambarkan dalam alur. Dalam cerita pendek, peristiwa dideskripsikan dengan kata-kata (bahasa) sebagai gambaran 
imajinasi pengarang terhadap suatu peristiwa yang dibayangkan (Kurniawan, 2011: 63).

Sebagai karya sastra fiksi, cerita pendek (cerpen) merupakan keindahan yang dapat dinikmati. Sama halnya dengan cerpencerpen dalam Antologi Cerpen Mastera Dari Pemburu ke Terapeutik Pusat Bahasa Departemen Pendidikan Nasional. Cerpen-cerpen yang terkumpul dalam antologi tersebut di atas tidak terlepas dari dua tarikan antara menjadi sajian peristiwa semata-mata pada satu sisi ekstrim dan menjadi paparan pemikiran semata-mata pada sisi ekstrim lainnya. Ada cerpen yang berisi tuturan tentang seseorang dan lainnya menghadapi persoalan, terlibat dalam suatu peristiwa dilengkapi dengan sajian percakapan dalam dengan dirinya atau dengan kita selaku pembacanya dan dialog dengan tokoh lain yang turut terlibat dalam peristiwanya langsung. Ada cerpen yang memaparkan pemikiran pengarang, mungkin berupa monolog yang terkadang menyapa kita selaku pembaca tentang berbagai pemikiran yang terkait dengan pokok persoalan yang dipilihnya. Ada juga cerpen yang mengandung porsi peristiwa dan porsi pemikiran secara proporsional.

Cerpen-cerpen yang terkumpul dalam Antologi Cerpen Mastera Dari Pemburu ke Terapeutik juga menyajikan peristiwa dan pemikiran yang selalu terkait dengan kehidupan kemanusiaan. Peristiwa kehidupan nyata, yang tiba, yang menimpa kita. Pemikiran yang menyebabkan kita berhadapan dengan nilai-nilai yang menjadi pegangan kita dalam mengisi dan mengarungi hidup ini, antara lain nilai sosial, nilai agama, nilai budaya, dan nilai moral sehingga cerpencerpen dalam Antologi Cerpen Mastera Dari Pemburu ke Terapeutik ini memiliki fungsi memberikan moral yang baik terhadap pembaca, memberikan hiburan agar dapat melupakan sejenak kesedihannya dan konflik yang terjadi di dunia nyata, memberikan pengetahuan tentang ajaran agama, sebagai pengarah untuk mendidik pembacanya karena terdapat nilai kebaikan dan kebenaran, dan menyajikan cerita yang dapat dinikmati keindahannya oleh pembaca.

Cerpen-cerpen yang terkumpul dalam Antologi Cerpen Mastera tersebut di atas sangat menarik. Karena di dalam Antologi Cerpen Mastera Dari Pemburu ke Terapeutik terdapat untaian kisah yang menarik yang menyuguhkan berbagai tema seperti: perburuan kehidupan spiritual yang disampaikan dalam bahasa yang puitis mewujud menjadi dongeng yang memikat, cinta segitia yang mengungkapkan kenangan dan kerinduan akan cinta yang dikemas sangat menarik serta pemakaian diksi bahasa jawa yang indah, penderitaan seorang perempuan korban perang, kehidupan pelacur yang diungkapkan dalam bahasa yang khas dan selaras, kehidupan gelandangan, sikap dan perilaku dalam hidup dengan menyajikan tokoh-tokoh Islam dan pasangannya yang serasi sebagai karya yang sarat dengan beban filosofis, wabah penyakit yang menyerang saraf berbahasa menggunakan bahasa yang aneh, orientalisme yang sarat dengan gugatan politik tertentu. Banyak perumpamaan atau majas yang indah, diksi yang tepat dan menarik dalam cerita pendek tersebut. Penggunaan gaya bahasa tersebut dapat mewakili keindahan gaya bahasa khas yang digunakan pengarang dalam cerita pendeknya.

Bahasa yang digunakan dalam cerpen berbeda dengan bahasa karya ilmiah atau tulisan yang lain. Bahasa dalam sastra khususnya cerpen biasanya menggunakan bahasa yang bersifat konotatif atau mengandung makna kias. Untuk mengetahui penggunaan gaya bahasa dalam karya sastra dapat dilakukan dengan kajian stilistika. Kajian stilistika mengungkapkan bagaimana cara pemanfaatan bahasa yang digunakan dalam karya sastra. Selain itu kajian stilistika juga mengungkapkan bagaimana 
efek bahasa yang digunakan dalam karya sastra.

Pembelajaran sastra di tingkat SMP saat ini sudah diarahkan pada kegiatan apresasi sastra. Peserta didik langsung dihadapkan dengan karya sastranya. Tujuan pembelajaran sastra di tingkat SMP/MTs adalah agar peserta didik menikmati dan memanfaatkan karya sastra untuk memperluas wawasan, memperluas budi pekerti, serta meningkatkan pengetahuan dan kemampuan berbahasa; menghargai dan membanggakan sastra Indonesia sebagai khasanah budaya dan intelektual manusia Indonesia (BSNP, 2006:110).

Dalam pembelajaran sastra kajian stilistik merupakan hal yang penting dilakukan. Dikatakan penting dilakukan karena adanya harapan bahwa dengan kajian ini dapat memberikan kajian yang lebih mendalam mengenai bagaimana mengapresiasi sebuah karya sastra khususnya cerpen. Selain itu pula dapat memperkaya pengetahuan siswa tentang peristiwa-peristiwa kehidupan yang disajikan dalam cerpen-cerpen tersebut.

Agar dapat memilih bahan pembelajaran sastra yang tepat, ada beberapa aspek yang perlu dipertimbangkan. Aspek yang dimaksud meliputi bahan pembelajaran yang sesuai dengan perkembangan siswa, tingkat kesulitan dilihat dari segi bahasa yang digunakan, nilai-nilai yang terkandung dalam bahan pembelajaran tersebut. Berdasarkan uraian tersebut kajian stilistika yang terkandung dalam cerpen dapat dijadikan alternatif bahan pembelajaran sastra di sekolah dan penting untuk dilakukan kajian.

Berdasarkan uraian diatas, penulis ingin meneliti unsur pemakaian bahasa figuratif dan fungsi bahasa dalam cerpen khususnya cerpen yang berjudul Antologi Cerpen Mastera Dari Pemburu ke Terapeutik Pusat Bahasa Departemen Pendidikan Nasional dan Pembelajaran Stilistika di SMP.
Tujuan penelitian ini adalah untuk (1) mendeskripsikan aspek bahasa figuratif dalam Antologi Cerpen Mastera Dari Pemburu ke Terapeutik Pusat Bahasa Departemen Pendidikan Nasional, (2) mendeskripsikan fungsi bahasa dalam Antologi Cerpen Mastera Dari Pemburu ke Terapeutik Pusat Bahasa Departemen Pendidikan Nasional, dan (3) mendeskripsikan pembelajaran stilistika Antologi Cerpen Mastera Dari Pemburu ke Terapeutik Pusat Bahasa Departemen Pendidikan Nasional pada siswa SMP.

Kajian aspek kebahasaan dalam karya sastra lazimnya dikategorikan sebagai kajian stile dengan sebutan stilistika. Leech \& Short (dalam Nurgiyantoro, 2014: 75) mengungkapkan bahwa stilistika merupakan kajian tentang stile, kajian stilistika terhadap wujud performansi kebahasaan, khususnya yang terdapat dalam teks-teks kesastraan. Abrams (1981: 192), menyatakan bahwa fitur stilistika (stylistic features) adalah fonologi, sintaksis, leksikal, dan retorika yang meliputi karakteristik penggunaan bahasa figuratif, pencitraan, pola rima, dan mantra. Adapun Leech \& Short (1984: 75-80) berpendapat bahwa unsur stilistika meliputi unsur leksikal, gramatikal figure of speech, serta konteks dan kohesi. Pradopo (2004: 9-14) menyatakan bahwa unsur-unsur gaya bahasa itu meliputi: (1 intonasi, (2) bunyi, (3) kata, (4) kalimat, dan (5) wacana.

Kajian stilistika di dalam penelitian ini dipahami untuk menganalisis unsur pemakaian bahasa figuratif, fungsi bahasa, dan pembelajaran stilistika Antologi Cerpen Mastera Dari Pemburu ke Terapeutik Pusat Bahasa Departemen Pendidikan Nasional pada siswa SMP.

Antologi Cerpen Mastera ini merupakan hasil kegiatan Program Penulisan Mastera (Cerpen) kerja sama kesastraan antara tiga negara Asean berbahasa Melayu/ Indonesia dalam Majelis Sastra Asia Tenggara (Mastera) sejak tahun 1995. Melalui majelis itu, tiga 
negara anggota, yakni, Brunei Darussalam, Indonesia, dan Malaysia, telah bersepakat untuk berbagi tugas dalam mewujudkan cita-cita mengembangkan sastra berbahasa Melayu/Indonesia di peringkat Internasional. Antologi cerpen mastera Dari Pemburu ke Terapeutik oleh Pusat Bahasa Departemen Pendidikan Nasional, diterbitkan oleh PT Remaja Rosda Karya Bandung, tahun 2005, ISBN 979-692402-1.

Pembelajaran stilistika Antologi Cerpen Mastera Dari Pemburu ke Terapeutik disesuaikan dengan Kurikulum 2013 yang dirumuskan dalam RPP yaitu pada KI 3/3.6 dan KI 4/4.6 yang meliputi kompetensi pengetahuan dan kompetensi keterampilan tentang aspek kebahasaan cerita pendek.

Secara etimologis stilistika berasal dari kata style yang berarti 'gaya'. Style atau yaitu cara khas yang dipakai pengarang untuk mengungkapkan diri. Cara pengungkapan tersebut dapat meliputi setiap aspek bahasa (kata-kata, metafora, susunan kalimat, nada, dan sebagainya). Stile, (style, gaya bahasa) adalah cara pengucapan bahasa dalam prosa, atau bagaimana seorang pengarang mengungkapkan sesuatu yang akan dikemukakan (Abrams dalam Nurgiyantoro, 2010: 276). Stile ditandai oleh ciri-ciri formal kebahasaan seperti pilihan kata, struktur kalimat, bentuk-bentuk bahasa figuratif, dan penggunaan kohesi. Stile pada hakikatnya merupakan teknik, teknik pemilihan ungkapan kebahasaan yang dirasa dapat mewakili sesuatu yang akan diungkapakan. Teknik itu sendiri, merupakan suatu bentuk pilihan dan pilihan itu dapat dilihat pada bentuk ungkapan bahasa seperti yang dipergunakan dalam sebuah karya (Nurgiyantoro, 2010: 277).

Stilistika merupakan ilmu yang menyelidiki bahasa yang dipergunakan dalam karya sastra. Stilistika menyaran pada pengertian studi tentang stile, kajian terhadap wujud performansi kebahasaan, khususnya yang terdapat di dalam karya sastra. Kajian stilistika itu sendiri sebenarnya dapat ditujukan terhadap berbagai ragam penggunaan bahasa, tak terbatas pada sastra saja namun biasanya stilistika lebih sering dikaitkan dengan bahasa sastra (Chapman dalam Nurgiyantoro, 2010: 279).

Ratna (2009: 3) menjelaskan bahwa stilistika (stylist) adalah ilmu tentang gaya, sedangkan stile (style) secara umum adalah cara-cara yang khas, bagaimana segala sesuatu diungkapkan dengan cara tertentu, sehingga tujuan yang dimaksudkan dapat dicapai secara maksimal. Gaya merupakan salah satu cabang ilmu tertua dalam bidang kritik sastra. Makna-makna yang diberikan sangat kontroversial, relevansinya menimbulkan banyak perdebatan.

Berdasarkan pendapat-pendapat tersebut dapat disintesiskan bahwa stilistika adalah ilmu yang mempelajari gaya bahasa yang dilakukan oleh penulis melalui karya sastra.

Kedudukannya sebagai teori dan pendekatan penelitian terhadap karya sastra yang berorientasi linguistik atau menggunakan wawasan dengan parameter linguistik, stilistika mempunyai tujuan sebagai berikut antara lain, (1) stilistika untuk menelaah bagaimana unsur-unsur bahasa ditempatkan dalam menghasilkan pesan-pesan aktual lewat pola-pola yang digunakan dalam sebuah karya sastra, (2) stilistika untuk menghubungkan intuisiintuisi tentang makna-makna dengan polapola bahasa dalam teks (sastra) yang dianalisis, (3) kajian stilistika akan menemukan kiat pengarang dalam memanfaatkan kemungkinan yang tersedia dalam bahasa sebagai sarana pengungkapan makna dan efek estetik bahasa (Sudjiman, 1995: v-vi), dan (4) stilistika untuk menghubungkan perhatian kritikus sastra dalam apresiasi estetik dengan perhatian linguis dalam deskripsi linguistik, seperti yang dikemukakan oleh 
Leech \& Short (1984: 13), tujuan kajian stilistika berada pada dua sisi yaitu (1) mencari fungsi estetik karya sastra, dan (2) mencari bukti-bukti linguistik. Dalam rangka mencari bukti-bukti fisik tersebut, proses kajian stilistika berkisar pada deskripsi segi-segi linguistik yang ada dalam karya sastra. Sedangkan dalam proses mencari fungsi estetik, proses kajian stilistika berkisar pada apresiasi sastra.

Tujuan kajian stilistika hakikatnya adalah untuk menemukan dan menjelaskan ketepatan penggunaan bentuk-bentuk bahasa baik secara estetis maupun efektivitasnya sebagai sarana komunikasi. Fungsi estetis yang dimaksud mengenai penggunaan bentuk-bentuk bahasa yang mendukung suatu teks (Nurgiyantoro, 2010: 280).

Haryanta (2012: 40), menjelaskan bahwa cerpen adalah kisahan pendek (kurang dari 10.000 kata) yang memberikan kesan tunggal yang dominan, dan memusatkan diri pada satu tokoh atau pelaku cerita dalam satu situasi tertentu.

Ukuran panjang pendek seringkali menjadi ukuran untuk menentukan apakah suatu karya sastra prosa itu disebut cerpen, atau novel. Hal ini tentu tidak salah, karena ukuran memang menjadi salah satu ciri dari cerpen disamping ciri-ciri lain yang melekat. Misalnya ceritanya berpusat pada seorang tokoh saja.

Stilistika dalam penelitiannya dapat saja berangkat dari teori struktural. Yakni dengan menganalisis unsur-unsur yang membangun karya sastra. Setelah itu secara bersama-sama mengkaji aspekaspek stilistika dalam objek kajiannya. Hal ini tentu akan menjadikan hasil penelitiannya lebih kompleks. Artinya, selain aspek stilistika penelitian seperti ini juga akan bisa mendeskripsikan komponen-komponen lain yang membangun sebuah karya sastra.

Figuratif berasal dari bahasa Latin figura, yang berarti form, shape. Figura berasal dari kata 'fingere' dengan arti 'to fashion'. Beberapa ahli mengidentifikasikan bahasa figuratif sebagai bahasa retorika dalam karya sastra. Retorika merupakan pemberdayaan unsur-unsur bahasa baik yang menyangkut masalah pilihan kata dan ungkapan, struktur kalimat, segmentasi, penyusunan dan penggunaan bahasa kias, pemanfaatan bentuk citraan yang disesuaikan dengan tujuan. Adapun kekhasan, ketepatan, kebaruan pemilihan bentukbentuk pengungkapan tergantung pada kemampuan imajinasi dan kreativitas pengarang (Nurgiyantoro, 2010: 295296).

Bahasa figuratif merupakan retorika sastra, pengungkapannya dengan cara kias menyaran pada makna literal 'literal meaning', memanfaatkan bahasa sedemikian rupa untuk memperoleh efek estetis. Dalam kajian stilistika karya sastra mencakup majas, idiom, dan peribahasa. Majas, idiom, dan peribahasa dipandang representatif dalam mendukung gagasan pengarang, selain dari ketiganya cukup banyak dimanfaatkan para sastrawan dalam karyanya (Nurgiyantoro, 2010: 96).

Sedangkan unsur stile yang berwujud retorika itu, sebagaimana dikemukakan Abrams dalam Nurgiyantoro (2010: 296) terdiri dari bahasa figuratif 'figuratif language' dan wujud pencitraan 'imagery'. Sedangkan bahasa figuratif dibedakan ke dalam (1) 'figures of thought' atau 'tropes', dan (2) 'figures of speech, rhetorical figures', atau 'schemes'. Yang pertama merujuk pada penggunaan unsur kebahasaan yang menyimpang dari makna yang harfiah dan lebih menyaran pada makna literal 'meaning', sedangkan yang kedua lebih menunjuk pada masalah pengurutan kata, masalah permainan struktur. Jadi, yang pertama mempersoalkan pada pengungkapan dengan cara kias, sedangkan yang kedua dengan penyiasatan struktur. Stile ini yang merupakan retorika klasik, yang biasa 
dianggap hanya "gaya bahasa" (Nurgiyantoro, 2010: 296).

\section{Idiom}

Badudu, J.S. dan Sutan Mohammad Zain (1996: 525), menjelaskan bahwa idiom adalah kata atau kelompok kata yang khusus yang mempunyai arti kiasan; ungkapan. Sedangkan, Haryanta (2012: 92) menyatakan bahwa idiom adalah (1) konstruksi yang maknanya tidak sama dengan gabungan makna unsurnya, (2) bahasa dan dialek yang khas menandai suatu bangsa, suku, kelompok, dan lainlain.

Dari pendapat tersebut, dapat disimpulkan bahwa idiom adalah kata atau kelompok kata yang khusus yang mempunyai arti kiasan.

\section{Simile}

Konsep tentang simile sering disebut pula sebagai 'persamaan'. Simile atau persamaan merupakan gaya bahasa perbandingan. Perbandingan ini bersifat eksplisit karena ia secara langsung menyatakan sesuatu sama dengan yang lain. Oleh karena itu upaya yang digunakan dalam perbandingan ini juga bersifat eksplisit yaitu dengan kata-kata seperti: sama, sebagai, bagaikan, laksana, seperti, dan sebagainya (Keraf, 2010: 138).

\section{Metafora}

Metafora adalah majas perbandingan yang diungkapkan secara singkat dan padat; pemakaian kata atau kelompok kata bukan dengan arti yang sebenarnya, melainkan sebagai lukisan yang berdasarkan persamaan atau perbandingan tetapi tanpa kata pembanding (Haryanta, 2012: 165).

\section{Metonimia}

Metonomia (berasal dari bahasa Yunani meta 'bertukar' + onym 'nama' adalah sejenis gaya bahasa yang menggunakan nama suatu barang bagi sesuatu yang lain berkaitan erat dengannya (Tarigan, 2009: 121). Moeliono dalam
Tarigan (2009: 121), menyatakan bahawa metonimia adalah majas yang memakai nama ciri atau nama hal yang ditautkan dengan nama orang, atau hal, sebagai penggantinya. Kita dapat menyebut pencipta atau pembuatnya jika yang kita maksudkan ciptaan atau buatannya ataupun kita menyebut bahannya jika yang kita maksudkan barangnya.

\section{Personifikasi}

Personifikasi merupakan gaya bahasa perbandingan yang membandingkan benda mati atau tidak bergerak seoalah-olah bernyawa dan dapat berperilaku seperti manusia. Personifikasi barangkali termasuk gaya bahasa yang paling popular dan banyak dijumpai dalam bahasa prosa (Sutejo \& Kasnadi, 2009: 50). Sedangkan, Haryanta (2012: 206) menjelaskan bahwa personifikasi adalah majas yang membandingkan benda-benda tidak bernyawa seolah-olah memiliki sifat seperti manusia.

\section{Hiperbola}

Hiperbola merupakan gaya bahasa yang dipakai untuk melukiskan suatu keadaan secara berlebih-lebihan daripada sesungguhnya. Pembaca banyak menemukan hiperbola ini dipergunakan pengarang untuk berbagai keperluan. Melukiskan konflik kemudian merajutnya menjadi klimaks, melukiskan karakter, dan mendeskripsikan pelataran prosa (Kasnadi dan Sutejo, 2010: 48).

\section{Asosiasi}

Asosiasi adalah majas yang menyatakan perbandingan terhadap dua hal yang berbeda, namun dinyatakan sama. Majas atau gaya bahasa ini ditandai oleh penggunaan kata bagai, bagaikan, seumpama, dan seperti (Haryanta, 2012: 25).

\section{Retoris}

Retoris merupakan gaya bahasa yang mempergunakan kalimat tanya yang 
sebenarnya tidak memerlukan jawaban karena sudah diketahuinya. Dalam dialog prosa hal ini sering digunakan para pengarang (Sutejo dan Kasnadi, 2010: 50).

Istilah fungsi bahasa dapat disamakan dengan istilah penggunaan bahasa. Jadi, fungsi bahasa dapat diartikan bagaimana cara orang menggunakan bahasa. Bahasa memiliki fungsi yang didasarkan pada tujuannya. Finochiaro (dalam Soeparno, 2013: 23) membagi fungsi bahasa atas lima bagian yaitu personal, instrumental, interpersonal, referensial, dan imajinatif.

a. Fungsi personal (pribadi) yang dimaksud dengan fungsi personal (pribadi) adalah si penutur menyatakan sikap terhadap apa yang dituturkannya. Si penutur bukan hanya mengungkapkan emosi melalui bahasa, tetapi juga memperlihatkan emosi tersebut sewaktu menyampaikan tuturannya. Dalam hal ini pihak si pendengar juga dapat menduga apakah si penutur sedih, marah, atau gembira.

b. Fungsi instrumental (direktif), yaitu mengatur tingkah laku pendengar. Dalam hal ini bahasa tidak hanya membuat si pendengar melakukan sesuatu, tetapi melakukan kegiatan yang sesuai dengan yang diinginkan oleh si pembicara.

c. Fungsi interpersonal, yaitu kemampuan untuk membina dan menjalin hubungan, memelihara, memperlihatkan perasaan persahabatan atau solidaritas sosial.

d. Fungsi referensial, yaitu bahasa berfungsi sebagai alat untuk membicarakan objek atau peristiwa yang ada di sekeliling penutur atau yang ada dalam budaya pada umumnya.

e. Fungsi imajinatif, yaitu bahasa dapat digunakan untuk menyampaikan pikiran, gagasan, dan perasaan. Baik yang sebenarnya maupun yang hanya imajinatif.
Fungsi imajinatif ini biasanya berupa karya sastra (puisi, cerpen, dongeng) yang digunakan untuk kesenangan penutur, maupun para pendengarnya).

\section{METODE PENELITIAN}

Jenis penelitian ini adalah penelitian kualitatif. Objek dalam penelitian ini adalah aspek stilistika yang terdiri atas pemakaian bahasa figuratif, fungsi bahasa yang terdapat dalam Antologi Cerpen Mastera Dari Pemburu ke Terapeutik Pusat Bahasa Departemen Pendidikan Nasional, dan pembelajarannya di SMP. Data dalam penelitian ini adalah teks-teks yang mengandung bahasa figuratif yang terdapat dalam Antologi Cerpen Mastera Dari Pemburu ke Terapeutik Pusat Bahasa Departemen Pendidikan Nasional. Sumber data penelitian ini adalah Antologi Cerpen Mastera Dari Pemburu ke Terapeutik Pusat Bahasa Departemen Pendidikan Nasional. Teknik pengumpulan data penelitian ini adalah teknik dokumentasi. Instrumen utama penelitian ini yaitu human instrument atau peneliti sebagai instrument utama, dibantu kartu dan pencatat data.

\section{HASIL DAN PEMBAHASAN}

Pada bagian ini disajikan tiga pembahasan hasil penelitian, yaitu pemakaian bahasa figuratif, fungsi bahasa, dan pembelajaran stilistika di SMP.

\section{Pemakaian Bahasa Figuratif}

Bahasa figuratif yang terdapat dalam penelitian ini terdiri atas delapan jenis, yaitu idiom, simile, metafora, metonomia, personifikasi, hiperbola, asosiasi, dan retoris. Pembahasan hasil penelitian aspek bahasa figuratif disajikan sebagai berikut:

\section{a. Idiom}

Pembahasan idiom pada penelitian ini dibatasi hanya mengambil tiga idiom pada setiap cerpen. Adapun pembahasan idiom pada delapan cerpen yang diteliti 
dapat diketahui pada pembahasan hasil penelitian berikut ini.

Pemilihan dan pemakaian idiom dalam cerpen tersebut cukup produktif. Hal ini terlihat pada jumlah idiom yang ditemukan. Idiom-idiom tersebut menjadi bagian dari satuan kebahasaan yang berwujud kalimat. Idiom-idiom pada cerpen berjudul "Pemburu" karya Agus Noor digunakan untuk menyampaikan gagasan, pikiran pengarang secara terpilih. Artinya bahwa idiom-idiom ini memiliki nilai keindahan atau efek estetis tertentu yang tidak dapat digantikan, atau jika digantikan efek estetis yang ditimbulkan akan berbeda. Jika idiom yang terdapat pada data (1) berikut misalnya digantikan dengan idiom /mandi bulan/, akan memiliki makna dan nilai estetis yang berbeda. Hal tersebut dapat diperhatikan dalam beberapa contoh idiom berikut ini.

(1) mandi cahaya (PT: 2) " Seperti juga semua makhluk yang ketakutan mendengar gemuruh kaki kami merasa benar-benar sendiri, ditangkap sunyi daun-daun yang mandi cahaya"

(2) gairah petualangan (PT: 8) "Semua itu bukan lagi gairah petualangan dan tantangan, tetapi penaklukan yang membosankan."

(3) tabir ruang (PT: 11) "Tiba-tiba tubuh mereka bilang tak berbekas bagai masuk ke tabir ruang dan waktu pada dimensi lain, tertelan dan lenyap".

Pada data nomor (1) pengarang melukiskan suasana sunyi, semua makhluk ketakutan yang diakibatkan mendengar gemuruh kaki mereka sehingga mereka benar-benar merasa sendiri dan sepi yang tampak oleh daundaun yang bersinar karena pancaran sinar purnama, hal ini dipertegas oleh kata 'mandi cahaya'. Pada data (2) pengarang melukiskan bahwa mereka sudah merasakan kebosananan menganggap keinginan, hasrat, dan keberanian petualangan dan tantangan mereka sudah tidak sepadan sehingga telah kehilangan buruan yang mengasyikan. Pada data (3) pengarang menggambarkan suasana mereka yang masuk masjid tiba tiba lenyap dan raib begitu saja seolah-olah mereka masuk ke dalam tirai penyekat yang memisahkan ruang dan waktu. Pengarang begitu lihai dalam melukiskan suasana dengan penggunaan idiom sehingga efek estetis sangat dirasakan untuk memperindah gagasannya.

\section{b. Simile}

Adapun pembahasan simile pada delapan cerpen yang diteliti dapat diketahui pada pembahasan hasil penelitian berikut ini.

(1) Seperti juga semua makhluk yang ketakutan mendengan gemuruh kaki kami hingga kami merasa benarbenar sendiri, tangkap sunyi daundaun yang mandi cahaya. (PT: 1)

(2) Kami seperti mengejar kilat. (PT: 2)

(3) Seperti batang-batang pohon yang bergoyang itu, seperti duan-daun yang melayang-layang, yang hanyut dibuai dzikir para kiai. (PT: 9)

Pada data (1) dalam cerpen ini, pengarang membandingkan semua makhluk dan angin mampu mendengar kedatangan para pemburu, bergegas pergi dan ketakutan mendengar gemuruh kaki mereka. Pada data (2) pengarang membandingkan pemburu seperti seseorang yang sedang mengejar kilat karena seluruh kekuatan dan pengalaman mereka telah dikeluarkan sampai tandas, tetapi buruan mereka tetap saja melenggang bebas, membuat pemburu merasa terhina dan sia-sia. Pada data (3) pengarang membandingkan batangbatang pohon yang bisa bergoyang, daunduan yang bisa terbang dan hanyut terbuai oleh dzikir para kiai sama seperti gema yang mampu melambung menyentuh langit serta gema yang membuat gemericik dalam hati. 


\section{c. Metafora}

(1) Kami adalah bangsa pemburu yang besar. (PT: 2)

(2) Lagu-lagu kami adalah lagu-lagu perburuan. (PT: 2)

(3) Legenda kami adalah penaklukan puluhan binatang buruan.

Pada data (1) kata bangsa pemburu termasuk ke dalam majas metafora karena memiliki arti bangsa yang telah berabadabad mengabdikan hidupnya untuk berburu. Pada data (2) kata lagu-lagu perburuan termasuk ke dalam metafora karena memiliki arti lagu-lagu yang dinyanyikan dalam pencarian binatang buruan. Pada data (3) kata penaklukan termasuk ke dalam metafora karena memilik makna perbuatan untuk menaklukan, menaklukan puluhan binatang buruan.

\section{d. Metonimia}

(1) Kami sudah tahu bagaimana menyembah Wildheheest, sejak kami masih dalam kandungan. (PT: 3)

Pengarang dalam mendeskripsikan ceritanya menyebut Wilddheheest atau sejenis mamalia herbivora yang tersebar di pedalaman Afrika yang berkerabat dekat dengan kambing sebagai sesembahan sejak mereka masih dalam kandungan. Pengarang menautkan sesembahan mereka sebagai penggantinya dengan sebutan Wildheheest.

\section{e. Personifikasi}

Personifikasi yang terdapat dalam cerpen "Pemburu" karya Agus Noor yaitu:

(1) Purnama mengapung di telaga, sesekali meleleh oleh arus gelombang. (PT: 1)

(2) Angin bergegas pergi oleh kedatangan kami. (PT: 1)
(3) Seperti juga semua makhluk yang ketakutan mendengar gemuruh kaki kami merasa benar-benar sendiri, ditangkap sunyi daun-daun yang mandi cahaya. (PT: 2)

\section{Pengarang, pada data}

melukiskan suatu benda yang berwujud purnama mampu mengapung di telaga yang lambat laun redup dan hilang oleh pergesaran air arus besar yang bergulunggulung. Pada data (2) pengarang melukiskan angin bisa bergerak pergi layaknya manusia setelah melihat kedatangan mereka. Pada data (3) pengarang melukiskan semua makhluk memiliki rasa takut seperti manusia dan hewan, ia mendengar suara kedatangan para pemburu pada kegelapan malam sunyi.

\section{f. Hiperbola}

Hiperbola yang terdapat dalam cerpen " Pemburu' karya Agus Noor yaitu:

(1) Seluruh kekuatan dan pengalaman kami sebagai pemburu telah kami keluarkan sampai tandas, tetapi kali ini buruan kami tetap saja melenggang bebas, memuat kami begitu terhina, seakan sia-sia kebesaran kami sebagai pemburu yang telah berabad-abad mengabdikan hidup dan peradaban kami hanya untuk berburu. (PT: 2)

(2) Kami sudah tahu bagaimana menyembah Wildeheest, sejak kami masih dalam kandungan. (PT: 3)

(3) Banyak di antara kami yang sudah berusia 7890 tahun, tetapi masih sanggup berlari mengejar antelop, kemudian menghantam binatang ini dengan kepalan tangan hingga pecah berantakan. (PT: 4) 
Pada data (1) pengarang dalam mengungkapkan cerita menggunakan kata yang berlebih-lebihan yaitu mengeluarkan kekuatannya sampai tandas dan sebagai pemburu yang telah berabad-abad. Pada data (2) pengarang juga menggunakan kata-kata yang berlebihan yaitu menyembah Wildheheest yaitu binatang khas afrika yang berkerabat dengan kambing. Pada data (3) pengarang menggunakan kata kata yang berlebihan yaitu seseorang yang mampu bertahan hidup sama berusia 7890 tahun masih sanggup mengejar antelop atau mamalia mirip kijang yang hidup di Afrika, Asia, dan Timur Tengah yang memiliki kecepatan lari yang luar biasa.

\section{g. Asosiasi}

Asosiasi yang terdapat dalam cerpen "Pemburu" karya Agus Noor yaitu:

(1) Barisan kiai masih antri di depan masjid itu, berkelok-kelok mengikuti gigir bukit, seperti barisan semut yang begitu tertib menuju lubang sarang mereka. (PT: 10)

(2) Batang-batang pohon yang bergoyang itu seperti daun-daun yang melayang, yang hanyut dibuai dzikir para kiai. (PT: 10)

(3) Tiba-tiba tubuh mereka hilang tak berbekas bagai masuk ke tabir ruang dan waktu pada dimensi lain, tertelan dan lenyap. (PT: 11)

Pada data (1) termasuk asosiasi karena pengarang dalam meuliskan cerita membandingkan sesuatu dengan yang lainnya. Antrian kiai dibandingkan dengan barisan semut yang begitu tertib. Pada data (2) pengarang membandingkan batangbatang pohon dengan daun-daun yang melayang. Pada data (3) pengarang membandingkan hilangnya tubuh tak berbekas seolah-olah masuk ke tabir dan waktu dimensi lain.

\section{h. Retoris}

Retoris yang terdapat dalam cerpen" Pemburu" karya Agus Noor yaitu:

(1) Kami adalah bangsa pemburu yang besar. Siapakah yang tak tahu akan hal ini? Kami tak pernah gagal memburu sesuatu. Telah kami jelajahi seluruh hutan. (PT: 2)

(2) "Takdir tak bisa dihentikan. Lantas bagaimana? Apa pun yang terjadi kita mesti memburu sesuatu!" (PT: 4)

(3) Apa arti kekuatan bila tak ada tantangan yang sepadan? Taka ada lagi yang sanggup melawan kami. (PT: 7)

Pada data (1) merupakan majas retoris karena pengarang menanyakan tentang bangsa pemburu, pengarang langsung memberikan jawaban sendiri bahwa mereka telah menjelajahi seluruh hutan. Pada data (2) merupakan majas retoris karena pengarang mengajukan pertanyaan tentang takdir apakah bisa dihentikan, pengarang langsung menjawab bahwa kita mesti memburu sesuatu. Pada data (3) pertanyaan tentang kekuatan tanpa tantangan langsung dijawab bahwa tak ada lagi yang sanggup melawan kami.

\section{Fungsi Bahasa dalam Antologi Cerpen Mastera Dari Pemburu ke Terapeutik}

Dalam kumpulan cerpen tersebut terdapat lima fungsi bahasa, di antaranya yaitu fungsi personal, fungsi instrumental, fungsi interpersonal, fungsi referensial, fungsi metalinguistik, dan fungsi imajinatif. Pada bagian ini disajikan pembahasan hasil penelitian fungsi bahasa sebagai berikut. 


\section{a. Fungsi Personal}

Tiga kutipan yang termasuk fungsi personal dalam cerpen "Pemburu" karya Agus Noor adalah sebagai berikut.

(1) Kami beristirahat di pinggir telaga itu; hanyut oleh pikiran kami; meletakkan semua senjata yang selama ini kami jinjing dan gendong. (PT: 2)

(2) Sebagian dari kami langsung merebahkan tubuh atau bersandarkan pda batang pohon dan gundukan batu. (PT: 2)

(3) Sebagian lagi menyempatkan diri membersihkan wajah terlebih dahulu, melulurkan kesejukan pada lengan dan kaki yang bengkak. (PT: 2)

Pada data (1) termasuk fungsi personal karena penutur menyatakan sikap terhadap apa yang dituturkannya. Si penutur bukan hanya mengungkapkan emosi melalui bahasa tetapi juga penutur menyatakan keputusannya untuk beristirahat di pinggir telaga itu dan meletakkan semua senjata yang selama itu mereka jinjing dan gendong. Pada data (2) penutur menyatakan sikapnya untuk merebahkan tubuhnya bersandar pada pohon dan gundukan tanah. Pada data (3) penutur menyatakan sikapnya bahwa sebagian lagi menyempatkan diri membersihkan wajah terlebih dahulu, melulurkan kesejukan pada lengan dan kakinya yang bengkak. Dalam pihak ini diduga si penutur dalam keadaan sangat kelelahan.

\section{a. Fungsi Instrumental}

Kutipan yang termasuk fungsi instrumental dalam cerpen "Pemburu" karya Agus Noor adalah sebagai berikut.

(1) "Apa pun yang terjadi kita mesti memburu sesuatu!" "Memburu apa?" itu membuat kami terdiam. Sampai kemudian ide brilliant terlontar. Kami akan memburu manusia untuk menggantikan binatang yang kini telah musnah. Kami pun membeli ratusan budak. Mereka kami beri kesempatan untuk melarikan diri. Mereka kami lepas ke hutan membiarkan mereka lari dan menghilang, baru kemudian kami memburu mereka. Itu menjadikan kami begitu bahagia. (PT: 4)

(2) Kepada mereka kami tawarkan kebebasan, "Masuklah ke dalam hutan, lari. Selamatkan kehidupanmu. Jangan cemas meski kami akan memburu kalian. Kalian masih punya kesempatan untuk memperpanjang kehidupan. Meskipun kalian juga tak luput dari kematian. (PT: 5)

(3) Tapi, itu lebih baik bagi kalian daripada mati di tiang gantungan taklagi punya pilihan. Mati dalam perburuan ini lebih terhormat bagi kalian. Anggap semua ini hanya permainan. Semoga nasib baik bersama kalian. (PT: 5)

Pada data (1) dengan bahasa, penutur mengatur tingkah laku agar mereka melakukan perintahnya memburu manusia untuk menggantikan binatang yang kini telah musnah dengan cara membeli ratusan budak untuk dilepas di hutan kemudian dijadikan hewan buruan. Pada data (2) penutur memberikan kebebasan agar mereka masuk ke dalam hutan untuk memperpanjang hidupnya meskipun tak akan luput dari kematian. Pada data (3) penutur menegaskan dan meyakinkan kepada mereka yang akan dijadikan hewan buruan untuk menjalankan kebebasannya bahwa hal tersebut lebih baik dan terhormat daripada harus mati di tiang gantungan.

\section{b. Fungsi Interpersonal}

Kutipan yang termasuk fungsi interpersonal dalam cerpen "Pemburu" karya Agus Noor adalah sebagai berikut. 
1) Nenek moyang kami telah membentuk kami sebagai pemburu paling ulung. (PT: 2)

2) Lagu-lagu kami adalah lagu-lagu perburuan. (PT: 2)

3) Legenda kami adalah penaklukan puluhan binatang buruan. (PT: 2)

Pada kutipan cerpen pemburu tersebut termasuk fungsi interpersonal karena bahasa yang digunakan penutur berfungsi untuk membina, menjalin, memelihara persahabatan atau solidaritas sosial. Hal ini dapat dibuktikan pada data (1) bahwa mereka telah dibentuk menjadi pemburu yang ulung oleh nenek moyang mereka. Pada data (2) mereka mengakui bahwa lagu mereka adalah lagu perburuan. Pada data (3) mereka menyatakan bahwa sejarah mereka adalah penaklukan puluhan binatang buruan.

\section{c. Fungsi Referensial}

Kutipan yang termasuk fungsi referensial dalam cerpen "Pemburu" karya Agus Noor adalah sebagai berikut.

(1) Kami adalah bangsa pemburu yang besar. Siapakah yang tak tahu akan hal itu? Kami tak pernah gagal memburu sesuatu. Telah kami jelajahi seluruh hutan. Telah kami jelajahi seluruh hutan. Telah kami sibak semua palung lautan. Nenk moyang kami telah membentuk kami sebagai pemburu paling ulung. (PT: 2)

(2) Kami tak pernah tergoda menjadi petani atau pedagang. Tak ada yang lebih terhormat bagi kami, nenek moyang, dan anak cucu kami, selain menjadi seorang pemburu yang besar yang sanggup merobohkan gajah dengan satu gerakan. Cerita-cerita penaklukan mengantar tidur anakanak kami menjadi hutan lebat dalam kepala mereka. Setiap dari kami dibesarkan dalam belukar. Kami sudah tahu bagaimana menyembah wildeheest, sejak kami masih dalam kandungan. Kami mengembara dari satu benua ke benua lainnya untuk memburu binatang-binatang, bukan sebagai cara kami bertahan menghadapi hidup, tetapi lebih untuk kebanggaan dan kehormatan. (PT: 3)

(3) Rupanya tak hanya kami yang suka dengan permainan semacam itu. Ketika kisah-kisah kami menjalar ke banyak negara, banyak orang di luar suku kami, mendatangi kami untuk ikut menikmati perburuan itu. Mulamula banyak di antara kami yang menolak karena hal itu dianggap akan mengotori kemurnian darah pemburu kami. Tetapi, kami tak bisa menolak ketika dari kami banyak yang datang kepada kami itu adalah para jendral, orang-orang besar di negara mereka, para raja, puluhan kepala negara, para bangsawan, dan pengusaha besar. (PT: 5-6)

Pada kutipan tersebut di atas termasuk fungsi referensial karena bahasa berfungsi sebagai alat untuk membicarkan objek atau peristiwa yang ada di sekeliling penutur yang ada dalam budaya masyarakat. Hal ini dijelaskan pada data (1) bahwa mereka adalah pemburu yang besar, mereka tak pernah gagal memburu sesuatu, mereka telah menjelajahi seluruh hutan, telah menyibak semua palung lautan. Nenek moyang mereka telah membentuknya sebagai pemburu paling ulung.

Pada data (2) pengarang tak pernah tergoda menjadi petani atau pedagang, tak ada yang lebih terhormat bagi mereka, nenek moyang, dan anak cucu mereka selain menjadi seorang pemburu yang besar yang sanggup merobohkan gajah dengan satu gerakan. Cerita-cerita penaklukan mengantar tidur anak-anak kami menjadi hutan lebat dalam kepala mereka. Setiap dari mereka dibesarkan dalam belukar. Mereka sudah tahu bagaimana menyembah Wildeheest, sejak 
mereka masih dalam kandungan, mengembara dari satu benua ke benua lainnya untuk memburu binatang-binatang, bukan sebagai cara untuk bertahan menghadapi hidup, tetapi lebih untuk kebanggaan dan kehormatan.

Pada data (3) pengarang menjelaskan bahwa kisah perburuan menjalar ke banyak negara, banyak orang di luar suku, mendatangi bangsa pemburu untuk ikut menikmati perburuan, ada para jendral, orang-orang besar di negara mereka, para raja, puluhan kepala negara, para bangsawan, dan pengusaha besar ingin bergabung menjadi pemburu.

\section{e. Fungsi Imajinatif}

Kutipan yang termasuk fungsi imajinatif dalam cerpen "Pemburu" karya Agus Noor adalah sebagai berikut.

(1) Kami seperti mengejar kilat. Seluruh kekuatan dan pengalaman kami sebagai pemburu telah kami keluarkan sampai tandas, tetapi kali ini buruan kami tetap saja melenggang bebas, membuat kami merasa terhina, seakan-akan sia-sia kebesaran kami sebagai pemburu yang telah berabad-abad mengabdikan hidup dan peradaban hanya untuk berburu. (PT: 2)

(2) Kami tak lagi hanya terbiasa dengan bunyi pedang, tetapi juga denting gelas dalam kehangatan pesta. (PT: 6)

(3) Kami berdiri di puncak menara peradaban, sendiri. Itu sering membuat kami terusik sunyi. (PT: 7)

Pada kutipan cerpen tersebut di atas termasuk fungsi imajinatif karena bahasa digunakan untuk menyampaikan pikirn, perasaan, dan gagasan baik yang sebenarnya maupun yang imajinatif. Hal ini dapat ditemukan pada data (1) pengarang mengungkapkan perasaanya bahwa mereka seperti mengejar kilat. Seluruh kekuatan dan pengalamanya sebagai pemburu telah dikeluarkan sampai tandas, tetapi kali ini buruan kami tetap saja melenggang bebas, membuat mereka merasa terhina, seakan-akan sia-sia kebesaran mereka sebagai pemburu.

Pada data (2) pengarang mengungkapkan perasaannya bahwa mereka tak lagi hanya terbiasa dengan bunyi pedang, tetapi juga denting gelas dalam kehangatan pesta. Pada data (3) pengarang menyampaikan gagasannya bahwa mereka berdiri di puncak menara peradaban, sendiri. Itu sering membuatnya terusik sunyi.

\section{Pembelajaran Stilistika Antologi Cerpen Mastera Dari Pemburu ke Terapeutik}

Pembelajaran stilistika Antologi Cerpen Mastera Dari Pemburu ke Terapeutik ditempuh melalui Rencana Pelaksanaan Pembelajaran (RPP).

\section{PENUTUP}

Berdasarkan hasil penelitian dan pembahasannya dapat disimpulkan sebagai berikut ini. Pemakain bahasa figuratif dalam Antologi Cerpen Mastera Dari Pemburu ke Terapeutik Pusat Bahasa Departemen Pendidikan Nasional terletak pada stile pengarang dalam memanfaatkan bahasa figuratif yang berupa idiom, simile, metafora, metonomia, personifikasi, hiperbola, asosiasi, dan retoris. Pemakaian bahasa figuratif dalam cerpen pada penelitian ini mampu menyegarkan dan menghidupkan pengungkapan pesan agar lebih mengesankan, lebih hidup, lebih jelas, lebih tegas, dan lebih menarik.

Fungsi bahasa dalam cerpen pada penelitian ini memiliki fungsi personal , fungsi instrumental, fungsi interpersonal, fungsi referensial, dan fungsi imajinatif. Bahasa memiliki fungsi yang didasarkan pada tujuannya.

Pembelajaran stilistika Antologi Cerpen Mastera Dari Pemburu ke Terapeutik dapat dijabarkan dalam RPP sebagi 
berikut: (1) merumuskan identitas, (2) merumuskan kompetensi inti, (3) merumuskan kompetensi dasar dan indikator pencapain kompetensi, (4) merumuskan tujuan pembelajaran, (5) merumuskan materi materi pembelajaran, (6) merumuskan media/alat pembelajaran, (7) merumuskan bahan dan sumber belajar, (8) merumuskan metode pembelajaran, (9) merumuskan kegiatan pembelajaran, dan (10) merumuskan penilaian.

Berdasarkan simpulan di atas, maka penulis menyarankan bahwa Hasil penelitian ini dapat memacu minat dan motivasi siswa untuk lebih mencintai sastra khususnya cerpen. Siswa mampu memahami fungsi bahasa didasarkan pada tujuannya. Hasil penelitian ini dapat dimanfaatkan sebagai bahan pembelajaran stilistika dan untuk melakukan penelitian yang lebih mendalam tentang unsur pemakaian bahasa figuratif dan fungsi bahasa, serta melakukan kajian tentang aspek-aspek stilistika yang lain, yaitu yang belum dikaji dalam penelitian ini. Bagi Guru Bahasa Indonesia SMP.

\section{DAFTAR PUSTAKA}

Al Ma'ruf, Ali Imron. 2012. Stilistika Teori, Metode, dan Aplikasi Pengkajian Estetika Bahasa. Surakarta: Cakra Books.

Aminudin. 1995. Stilistika Pengantar Memahami Bahasa dalam Karya Sastra. Semarang: IKIP Semarang Press.

Arikunto, Suharsimi. 2010. Prosedur Penelitian Suatu Pendekatan Praktik. Jakarta: Rineka Cipta.

Aziez, Furqonul dan Hasim Abdul. 2015. Menganalisis Fiksi Sebuah Pengantar. Bandung: Ghalia Indonesia.
Badudu, J.S. dan Sutan Mohammad Zain. 1996. Kamus Umum Bahasa Indonesia. Jakarta: Pustaka Sinar Harapan.

Bramantyo, Hendy. Tanpa Tahun. Buku Panduan Ejaan Bahasa Indonesia Yang Disempurnakan. Tanpa Kota: Grandmedia.

Bungin, Burhan. 2001. Metodologi Penelitian Sosial. Surabaya: Airlangga University Press.

Chaer, Abdul dan Leoni Agustina. 2004. Sosiolinguitik Perkenalan Awal. Jakarta: Rineka Cipta.

Departemen Pendidikan Nasional. 2007. Petunjuk Teknis Pengembangan Silabus dan Contoh Model Silabus Mata Pelajaran Bahasa Indonesia. Jakarta: BNSP.

Emzir. 2015. Metodologi Penelitian Pendidikan Kuantitatif dan Kualitatif. Jakarta: Rajawali Pers.

Haryanta, Agung Tri. 2012. Kamus Sastra Indonesia dan Kebahasaan. Surakarta: Aksara Sinergi Media.

Jabrohim. 2014. Senyum Karyamin Sebuah Tinjauan Stilistika. Yogyakarta: Pustaka Pelajar.

Jumirah. 2014. “Gaya Bahasa Metafora Pada Buku Kumpulan Cerpen "Madre" Karya Dwi Lestari". Skripsi. Purwokerto: Universitas Muhammadiyah Purwokerto.

Kasnadi dan Sutejo. 2010. Apresiasi Prosa Mencari Nilai, Memahami Fiksi. Ponorogo: Spectrum.

Kementerian Pendidikan dan Kebudayaan. 2014. Materi Pelatihan Guru Implementasi 
Kurikulum 2013 Tahun Pelajaran 2014/2015 Mata Pelajaran Bahasa Indonesia SMP/MTs. Jakarta: Kementerian Pendidikan dan Kebudayaan.

Kementerian Pendidikan dan Kebudayaan. 2018. Bahasa Indonesia SMP/MTs Kelas IX. Jakarta: Kementerian Pendidikan dan Kebudayaan RI.

Keraf, Gorys. 2004. Komposisi. Jakarta: Nusa Indah.

Keraf, 2010. Diksi dan Gaya Bahasa. Jakarta: Gramedia Pustaka Utama.
Kosasih, Engkos dan Restuti. 2016. Mandiri Bahasa Indonesia untuk SMP/MTs Kelas IX. Jakarta: PT Penerbit Erlangga.

Kridalaksana, Harimurti. 2009. Kamus Linguistik. Jakarta: Gramedia Pustaka Utama.

Kurniawan, Heru. 2011. Penulisan Sastra Kreatif. Lamongan: CV Pustaka Ilalang Group.

Mahsun. 2012. Metode Penelitian Bahasa Tahapan Strategi, Metode, dan Tekniknya. Jakarta: Rajawali Pers. 